ISSN 1119-7455

\title{
DETERMINATION OF KOLGRACE BIO-FERTILIZER RATE FOR OPTIMUM GREENGRAM (Vigna radiata L. Wilczek) PRODUCTION IN IBADAN, SOUTHWEST NIGERIA
}

\author{
${ }^{1}$ Ihejiofor P.N., ${ }^{* 1,2}$ Ukwu U.N. and ${ }^{1}$ Adeoye G. \\ ${ }^{1}$ Department of Agronomy, University of Ibadan, Ibadan, Nigeria \\ ${ }^{2}$ Department of Crop science, University of Nigeria, Nsukka, Nigeria \\ *Corresponding author's email: uchenna.ukwu@unn.edu.ng
}

\begin{abstract}
Greengram productivity has been improved by application of farmyard manures in the last two decades; however, these manures are not readily available as at when needed. In some cases, they are available but in limited supply. Kolgrace bio-fertilizer, a novel commercial product of the Association of Organic Agricultural Practitioners could serve as a superior alternative to farmyard manures. Hence, a field experiment was carried out at the Teaching \& Research Farm of the Department of Agronomy, University of Ibadan, Nigeria during the 2015 cropping season to evaluate the effects of five rates $\left(0.00,0.25,0.50,1.00\right.$, and $\left.2.00 t \mathrm{ha}^{-1}\right)$ of Kolgrace bio-fertilizer on the performance of greengram. The aim was to determine the optimum rate of application of this biofertilizer for greengram production. The experimental design was a randomized complete block design with four replications. Data were collected on growth and yield traits, and were subjected to analysis of variance. Results showed that Kolgrace rates significantly $(p<0.01)$ influenced all the traits measured with exception of fresh pod yield (FPY). Plant height $(112 \mathrm{~cm})$, number of leaves (87), stem girth $(1.43 \mathrm{~mm})$ and number of flowers (10) at 8 weeks after planting (WAP) were significantly highest with the application of $0.5 \mathrm{tha^{-1 }}$ whereas, $0.25 \mathrm{tha}^{-1}$ gave best results for number of pods (42) and pod yield $\left(3.85 \mathrm{tha}^{-1}\right)$. The application of $0.5 \mathrm{tha}^{-1}$ is, therefore, recommended if the interest of the farmer is sprout, fodder or green manure, and $0.25 \mathrm{tha}^{-1}$ if the interest is for seed production.
\end{abstract}

Key words: mungbean, underutilized crops, biofertilizer, pulse, alternative protein source

\section{INTRODUCTION}

Greengram (Vigna radiata (L) Wilczek), a member of the fabaceae family with diploid chromosome number $2 \mathrm{n}=22$ (Thulin, 1989) is relatively an unknown and underutilized leguminous pulse in Nigeria with enormous nutritional, medicinal and environmental (as cover crops and nitrogen fixer) potentials that are yet to be fully harnessed. Although an introduced crop in the region and a minor, it is fast gaining global recognition as an important food and cash crop. It is a small, round olive-green peas with sweet flavour and good texture. It is also known as mungbean, mungo, golden gram, Jerusalem pea in India, Philippines and in other regions of the world.

The crop is endeared to farmers owing to its attributes of short duration, low input requirement, suitability as a rotation crop in cereal-based systems, and good performance under heat and drought stress (Nair et al., 2020). It thrives in poor soils due to its ability to exist in a symbiotic association with mycorrhiza fungi (Kasiamdari et al., 2002) and specific bacteria, and can fix up to $50 \mathrm{~kg} \mathrm{ha}^{-1} \mathrm{~N}$ (Mandal et al., 2009), making it an excellent material for soil fertility maintenance, environmental conservation, food and income security, as well as in sustainable agriculture. It often requires less irrigation and nutrient elements than many other crops to produce appreciable yields (Kannaiyan, 1999).

Seeds of greengram contain an abundance of major food nutrients including protein, about $30 \%$ of dry matter (DM) (AVRDC, 2012), carbohydrate up to $45 \%$ of DM, fiber about $6.5 \%$ of DM (Heuzé et al., 2015), and some essential amino acids which explains its revered position as the most nutritious pulse known (Anjum et al., 2011). In addition, the protein, ash, fiber and mineral contents of mungbean can significantly be improved by increasing the malting periods (Onwurafor et al., 2020). Medicinally, mungbean has been used in China and India in the prevention and treatment of varied health-related ailments due to the overwhelming high levels of phytochemicals including vitexin, isovitexin, total phenols, flavonoids and other compounds in the grains and sprouts (Cao et al., 2011; Kim et al., 2012). Mungbean can be utilized as a pulse, vegetable, and fodder or green manure. Grains can be cooked with rice or sugar to make sweet desert soup, grilled or roasted as a snack. Sprouts are used to garnish noodles and pancakes, in vegetable salads,

Please cite as: Ihejiofor P.N., Ukwu U.N. and Adeoye G. (2022). Determination of Kolgrace bio-fertilizer rate for optimum greengram (Vigna radiata L. Wilczek) production in Ibadan, South West, Nigeria. Agro-Science, 21 (1), 82-87. DOI: https://dx.doi.org/10.4314/as.v21i1.13 
and in preparing chicken soups. Mungbean starch is an essential ingredient in making noodles while its paste is an integral component of sweets. As the search for cheap, alternative and accessible sources of affordable food nutrients intensifies in Nigeria and other regions of the world (Ihejiofor, 2020), mungbean is fast taking the lead as an emerging source of easily digestible protein, carbohydrate, amino acids and fibre that can help diversify food production in the country, adding new species to our diets and providing better supply of essential nutrients. Although, yet to gain full acceptance as a food source in Nigeria, and some parts of Africa, its prospective roles in therapeutic medicine, soil fertility management, environmental conservation, food security and sustainable agriculture cannot be underestimated as the growing hunger persist.

Global average yield of mungbean is $721 \mathrm{~kg} \mathrm{ha}^{-1}$ which is low, although yield of 2.5-3.8 $\mathrm{t} \mathrm{ha}^{-1}$ is possible (Sadeghipour et al., 2010; AVRDC, 2012) with improved varieties and adequate management. Ogunwale et al. (2002) reported that low soil fertility is one major factor limiting crop production in Nigeria, as is the case with most tropical and subtropical regions of the world. There is a preponderance of literature on the effect of pig, cow and poultry manure on performance of mungbean (Akinmutimi and Amaechi, 2015; Mahabub et al., 2016; Gadi et al., 2017; Ajoku et al., 2019), but these farmyard manures are not readily available as at when needed. In some cases, they are available in limited supply. Kolgrace biofertilizer, a novel commercial product of the Association of Organic Agricultural Practitioners, contains over twice as much the concentration of most essential nutrient elements (Table 1) reported for conventional sources of manure including poultry, cow dung, pig slurry, rabbit droppings and compost (Agbede et al., 2008; Adeniyan et al., 2011; Akinmutimi and Amaechi, 2015; AlJawhara, 2016; Ihejiofor et al., 2020). The biofertilizer is affordable and readily available. Earlier report by Ihejiofor et al. (2020) indicated that $0.5 \mathrm{t} \mathrm{ha}^{-1}$ of Kolgrace bio-fertilizer gave best results for growth and yield traits of greengram evaluated in the screenhouse. This research was therefore carried out to investigate the best rate of Kolgrace bio-fertilizer for greengram production under field conditions in Ibadan, Nigeria, a derived savanna agro-ecological zone.

\section{MATERIALS AND METHODS Experimental Site}

The experiment was carried out at the Teaching and Research Field of the Department of Agronomy, Parry Road, University of Ibadan, Nigeria. Parry Road has elevation of $189 \mathrm{~m}$ above sea level and situated at $07^{\circ} 27^{\prime} \mathrm{N}$ and $03^{\circ} 53^{\prime} \mathrm{E}$.

\section{Field Preparation, Treatments and Experimental Design}

The field was ploughed, harrowed and partitioned into blocks. Each block was sub-divided into plots on which seedbeds were made, with each plot measuring $1.0 \times 1.8 \mathrm{~m}$. The treatments comprised five application rates of an indigenous bio-fertilizer (Kolgrace); 0.00, 0.25, 0.50, 1.00 and $2.00 \mathrm{t} \mathrm{ha}^{-1}$ arranged in a randomized complete block design, and replicated four times. The selected treatment rates were informed by a preceding screenhouse study by Ihejiofor et al. (2020), where six Kolgrace rates $\left(0.00,0.50,1.00,2.00,4.00\right.$ and $\left.8.00 \mathrm{t} \mathrm{ha}^{-1}\right)$ were evaluated for growth and yield attributes, with $0.5 \mathrm{tha}^{-1}$ emerging as the best while 4 and $8 \mathrm{tha}^{-1}$ seemed wasteful, and repressed growth and yield. Rates above $0.5 \mathrm{t} \mathrm{ha}^{-1}$ were seen to have suppressed growth and yield, hence the inclusion of $0.25 \mathrm{tha}^{-1}$ in the current study. Seeds were planted at a spacing of $30 \mathrm{~cm} \times 10 \mathrm{~cm}$, with two seeds per hole which were later thinned to one at two weeks after planting (WAP). A spacing of $1 \mathrm{~m}$ was allowed between plots, and between blocks. Routine agronomic practices were carried out as at when due.

\section{Calculation of Manure Requirement per Plot}

The quantity of Kolgrace bio-fertilizer that was applied per plot was calculated as:

$$
\frac{\text { Quantity per hectare }(\mathrm{kg}) \times \text { Area of plot }\left(\mathrm{m}^{2}\right)}{\text { Area of one hectare }\left(\mathrm{m}^{2}\right)} \text {. }
$$

\section{Physicochemical Analyses of the Soil}

Particle size distribution of the soil was determined using Bouyoucous hydrometer method. Soil $\mathrm{pH}$, soil organic carbon, total $\mathrm{N}$, available $\mathrm{P}$, contents of the exchangeable bases and exchangeable acidity were also determined, adopting the standard laboratory procedures used by Obalum et al. $(2011,2012)$. Micronutrients ( $\mathrm{Mn}, \mathrm{Fe}, \mathrm{Cu}$ and $\mathrm{Zn}$ ) in the soil was extracted from the sample using $0.1 \mathrm{~N} \mathrm{HCl}$. Each of the elements was read off using atomic absorption spectrophotometer (Thomas, 1982).

\section{Data Collection}

Data were collected on selected growth and yield parameters such as plant height, number of leaves per plant, stem diameter, number of pods per plant, fresh pod weight and dry pod weight, from 3-5 representative plants at weekly intervals. Plant height was determined as the height from the base of the plant to the tip; number of leaves per plant was counted as number of fully expanded leaves; stem diameter per plant was taken at $2 \mathrm{~cm}$ from the base with a venier caliper. Number of pods per plant, fresh and dry pod yield per plant was taken as the average of 3-5 representative plants. The harvested fresh pods were sun-dried for 14 days to obtain the dry pod yield. Yield per hectare was calculated thus:

$$
\text { Pod yield ha-1 }=\frac{\text { Pod yield por plant }(t) \times \text { Area of } 1 \mathrm{ha}\left(\mathrm{m}^{2}\right)}{\text { Area occupied by one stand }\left(\mathrm{m}^{2}\right)}
$$




\section{Statistical Analysis}

All data were subjected to analysis of variance using Genstat statistical package ( $4^{\text {th }}$ Edition) and means that differed significantly were separated using Duncan's new multiple range test at $p<0.05$.

\section{RESULTS AND DISCUSSION}

\section{Physicochemical Properties of the Soil}

The result of the pre-planting physical and chemical analysis of the soil of the experimental site is shown in Table 1. The particle size distribution analysis of the soil showed that the soil is a sandy loam. The soil was slightly acidic with $\mathrm{pH}$ of 6.1 . Total $\mathrm{N}$, available $\mathrm{P}$ and exchangeable $\mathrm{K}$ in the soil exceeded the critical ranges of 2.1-2.4 $\mathrm{g} \mathrm{kg}^{-1}, 3-7$ $\mathrm{mg} \mathrm{kg}-1$ and $0.2-0.4 \mathrm{cmol} \mathrm{kg}^{-1}$, respectively. This shows that the soil is suitable for the experiment and that the application of Kolgrace bio-fertilizer would give a measurable response.

\section{Chemical Properties of Kolgrace Bio-Fertilizer}

The percentage composition of nutrient elements in Kolgrace bio-fertilizer are shown in Table 2. The bio-fertilizer has total $\mathrm{N}$ content of $4.6 \%$, $\mathrm{P}$ of $1.8 \%$ and $\mathrm{K}$ of $5.3 \%$. It is slightly alkaline with $\mathrm{pH}$ of 7.5. The analysis shows that the bio-fertilizer can provide an adequate amount of macro and micro nutrients for the experiment and may help increase the $\mathrm{pH}$ of the soil to tilt towards neutral.

Table 1: Pre-planting physicochemical properties of soil used for field study

\begin{tabular}{ll}
\hline Properties & Soil \\
\hline $\mathrm{pH}\left(\mathrm{H}_{2} \mathrm{O}-1: 1\right)$ & 6.1 \\
Particle size distribution $\left(\mathrm{g} \mathrm{kg}^{-1}\right)$ & \\
Sand & 786.0 \\
$\mathrm{Silt}$ & 104.0 \\
Clay & 110.0 \\
Texture & Sandy loam \\
Organic matter $\left(\mathrm{g} \mathrm{kg}^{-1}\right)$ & 18.7 \\
Organic carbon $\left(\mathrm{g} \mathrm{kg}^{-1}\right)$ & 10.9 \\
Total nitrogen $\left(\mathrm{g} \mathrm{kg}^{-1}\right)$ & 3.2 \\
Available phosphorus $\left(\mathrm{mg} \mathrm{kg}^{-1}\right)$ & 11.5 \\
Exchangeable cation & \\
Potassium $(\mathrm{K})\left(\mathrm{cmol} \mathrm{kg}^{-1}\right)$ & 1.1 \\
Calcium $(\mathrm{Ca})(\mathrm{cmol} \mathrm{kg}$ \\
Magnesium $(\mathrm{Mg})\left(\mathrm{cmol} \mathrm{kg}^{-1}\right)$ & 2.8 \\
Exchangeable hydrogen acidity $\left(\mathrm{g} \mathrm{kg}^{-1}\right)$ & 3.2 \\
Extractable micronutrients $\left(\mathrm{mg} \mathrm{kg}^{-1}\right)$ & 0.6 \\
Copper $(\mathrm{Cu})$ & \\
Manganese $(\mathrm{Mn})$ & 20.0 \\
Zinc $(\mathrm{Zn})$ & 352.0 \\
Iron $(\mathrm{Fe})$ & 246.0 \\
\hline
\end{tabular}

Effects of Application of Kolgrace Bio-fertilizer on Growth Parameters of Greengram

The effect of Kolgrace rates on plant height of greengram is shown in Table 3. There was no significant difference $(p>0.05)$ in plant height at 2 and 6 WAP, suggesting that the observable variation could be due to chance. Significant differences $(p<0.05)$ were, however, observed at 4, 5, 7 and 8 WAP. Kolgrace application rate of $0.5 \mathrm{t} \mathrm{ha}^{-1}$ consistently gave significantly $(p<0.05)$ taller plants than $0.00,1.00$ and $2.00 \mathrm{t} \mathrm{ha}^{-1}$ at $4(49.90 \mathrm{~cm}), 5(73.60 \mathrm{~cm}), 7$ $(105.70 \mathrm{~cm})$ and $8(112.90 \mathrm{~cm})$ WAP, but was similar to $0.25 \mathrm{t} \mathrm{ha}^{-1}$. The similar performance of 0.5 and $0.25 \mathrm{t} \mathrm{ha}^{-1}$ of Kolgrace bio-fertilizer, which were superior to the other rates support the reports of Rachie and Roberts (1974), Lawn and Russell (1978), Lawn and Ahn (1985), and Kannaiyan (1999) who asserted that greengram did not require heavy nutrient application to produce optimally.

The effect of different levels of Kolgrace biofertilizer on number of leaves is shown in Table 4. Non-significant differences $(p>0.05)$ were recorded at 2 and 4 WAP, even though, 0.25 and $0.5 \mathrm{t} \mathrm{ha}^{-1}$ application level recorded the highest mean value for number of leaves at 2 WAP (9.0) and 4 WAP (27.0), respectively. However, at $5 \mathrm{WAP}$, the rate $0.5 \mathrm{t} \mathrm{ha}^{-1}$ significantly increased $(p<0.05)$ leafiness, as this rate produced the highest number of leaves at 5 WAP (53.0), 6 WAP (66.0) and 7 WAP (85.0). At $8 \mathrm{WAP}, 2.0 \mathrm{t} \mathrm{ha}^{-1}$ gave the highest number of leaves (87.0) which was similar to $0.5 \mathrm{t} \mathrm{ha}^{-1}$ (82.0). These results show that leave production in greengram could be influenced largely by the amount of

Table 2: Analysis of Kolgrace bio-fertilizer versus chemical composition of commonly used organic manures

\begin{tabular}{lccll}
\hline Properties & Pig & Poultry & Compost & Kolgrace \\
\hline pH $\left(\mathrm{H}_{2} \mathrm{O}-1: 2\right)$ & 7.2 & $7.3-8.3$ & 7.8 & 7.5 \\
Total P (\%) & 0.3 & $0.9-4.1$ & 0.56 & 4.6 \\
Available P (\%) & 0.1 & $0.2-1.0$ & 0.26 & 1.8 \\
Potassium (\%) & 0.1 & $0.4-1.4$ & 1.15 & 5.3 \\
Calcium (\%) & 1.5 & $3.2-3.4$ & 3.77 & 5.2 \\
Magnesium (\%) & 0.7 & $1.0-1.1$ & 0.8 & 2.2 \\
Sodium (\%) & - & - & - & 0.1 \\
Zinc $\left(\mathrm{mg} \mathrm{kg}^{-1}\right)$ & 332.0 & $17.9-119.4$ & 361.7 & 15.3 \\
Iron $\left(\mathrm{mg} \mathrm{kg}^{-1}\right)$ & 438.0 & $5.0-39.8$ & 14.0 & 102.5 \\
Copper $\left(\mathrm{mg} \mathrm{kg}^{-1}\right)$ & 87.0 & $25.7-31.1$ & 245.0 & 31.0 \\
Manganese $\left(\mathrm{mg} \mathrm{kg}^{-1}\right) 33.4$ & $121.3-333.7405 .4$ & 344.5 \\
\hline
\end{tabular}

Chemical compositions of pig, poultry and compost manures were adapted from Malik et al. (2013); Steiner et al. (2019); Mian et al. (2020); Omar et al. (2020); Kolgrace chemical compositions were adapted from Ihejiofor et al. (2020).

Table 3: Effect of different rates of Kolgrace bio-fertilizer on plant height

\begin{tabular}{|c|c|c|c|c|c|c|}
\hline \multirow{2}{*}{ Rates $\left(\mathrm{t} \mathrm{ha}^{-1}\right)$} & \multicolumn{6}{|c|}{ Weeks after planting } \\
\hline & 2 & 4 & 5 & 6 & 7 & 8 \\
\hline 0 & $9.20 \mathrm{a}$ & $39.00 \mathrm{~b}$ & $57.70 \mathrm{~b}$ & $72.70 \mathrm{a}$ & $86.70 \mathrm{~b}$ & $97.30 \mathrm{~b}$ \\
\hline 0.25 & $10.97 \mathrm{a}$ & $48.00 \mathrm{ab}$ & $70.10 \mathrm{ab}$ & $85.70 \mathrm{a}$ & $102.80 \mathrm{a}$ & $109.60 \mathrm{a}$ \\
\hline 0.5 & $10.12 \mathrm{a}$ & $49.90 \mathrm{a}$ & $73.60 \mathrm{a}$ & $89.10 \mathrm{a}$ & $105.70 \mathrm{a}$ & $112.90 \mathrm{a}$ \\
\hline 1 & $8.60 \mathrm{a}$ & $40.60 \mathrm{ab}$ & $59.70 b$ & $76.80 \mathrm{a}$ & $92.80 \mathrm{~b}$ & $107.30 \mathrm{a}$ \\
\hline 2 & $8.33 \mathrm{a}$ & $39.60 \mathrm{~b}$ & $57.40 \mathrm{~b}$ & $75.60 \mathrm{a}$ & $89.90 \mathrm{~b}$ & $104.70 \mathrm{ab}$ \\
\hline
\end{tabular}

Means with same letter (s) are statistically similar to each other at $p<0.05$ 
Table 4: Effect of different rates of Kolgrace biofertilizer on number of leaves

\begin{tabular}{lllllll}
\hline Rates & \multicolumn{6}{c}{ Weeks after planting } \\
\cline { 2 - 7 }$\left(\mathrm{t} \mathrm{ha}^{-1}\right)$ & 2 & 4 & 5 & 6 & 7 & 8 \\
\hline 0 & $7.0 \mathrm{a}$ & $22.0 \mathrm{a}$ & $28.0 \mathrm{~b}$ & $37.0 \mathrm{c}$ & $37.0 \mathrm{c}$ & $47.0 \mathrm{~b}$ \\
0.25 & $9.0 \mathrm{a}$ & $25.0 \mathrm{a}$ & $40.0 \mathrm{~b}$ & $55.0 \mathrm{ab}$ & $67.0 \mathrm{ab}$ & $78.0 \mathrm{a}$ \\
0.5 & $8.0 \mathrm{a}$ & $27.0 \mathrm{a}$ & $53.0 \mathrm{a}$ & $66.0 \mathrm{a}$ & $85.0 \mathrm{a}$ & $82.0 \mathrm{a}$ \\
1 & $8.0 \mathrm{a}$ & $21.0 \mathrm{a}$ & $36.0 \mathrm{~b}$ & $49.0 \mathrm{ab}$ & $64.0 \mathrm{~b}$ & $77.0 \mathrm{a}$ \\
2 & $7.0 \mathrm{a}$ & $20.0 \mathrm{a}$ & $36.0 \mathrm{~b}$ & $47.0 \mathrm{~b}$ & $70.0 \mathrm{ab}$ & $87.0 \mathrm{a}$ \\
\hline \multicolumn{7}{l}{ Means with same letter(s) are similar to each other at $p<0.05$}
\end{tabular}

manure or bio-fertilizer applied. It has been reported severally that growth and yield of greengram increased with increasing rate of fertilizer application (Sadeghipour, 2010; Mahabub et al., 2016; Ajoku et al., 2019). However, such reports did not conform with the findings of this study, as the highest number of leaves was recorded at 5, 6 and 7 WAP when 0.5 $\mathrm{t} \mathrm{ha} \mathrm{a}^{-1}$ of Kolgrace bio-fertilizer was applied. It is also noteworthy that though $2 \mathrm{tha}^{-1}$ produced visibly higher number of leaves (87.0) at 8 WAP compared to $0.5 \mathrm{tha}^{-1}(82.0)$, the difference was not significant and hence, the former is not cost effective.

The effect of different rates of Kolgrace biofertilizer on stem diameter is presented in Table 5 . Variations observed across the various bio-fertilizer rates, were statistically insignificant $(p>0.05)$, until after 5 weeks. Although not-significant, the rate $0.5 \mathrm{t} \mathrm{ha}^{-1}$ was seen to favour stem diameter more than the other application rates, as it recorded the highest stem diameter of 0.22 and $0.71 \mathrm{~mm}$ at 2 and 4 WAP, respectively. The highest significant $(p<0.05)$ stem diameter, 1.17, 1.20, 1.36 and 1.43 $\mathrm{mm}$, were observed in plots treated with Kolgrace rate of $0.5 \mathrm{tha}^{-1}$ at 5, 6, 7 and $8 \mathrm{WAP}$, respectively. The significantly higher performance of lower rates $\left(0.25\right.$ and $\left.0.5 \mathrm{t} \mathrm{ha}^{-1}\right)$ is a function of the low nutrient requirement of the crop (Kannaiyan, 1999) and the rich potential of Kolgrace bio-fertilizer in releasing essential nutrients (Table 1).

\section{Effects of Application of Kolgrace Bio-fertilizer on Flowering and Yield Traits of Greengram}

The effects of Kolgrace bio-fertilizer rates on number of flowers in greengram were comparable $(p>0.05)$ at the onset of flowering at 6 WAP (Table 6). Significant variations $(p<0.01)$ were observed for number of flowers at the latter weeks. The rate $0.5 \mathrm{t} \mathrm{ha}^{-1}$ of Kolgrace bio-fertilizer gave significantly $(p<0.05)$ highest number of flowers (16.0) at 7 WAP, whereas $1.0 \mathrm{tha}^{-1}$ was highest at 8 WAP (10.0), 9 WAP (21.0) and 10 WAP (23.0). Plants that received no bio-fertilizer consistently produced the lowest number of flowers across the various bio-fertilizer rates and weeks, suggesting that flowering in mungbean can be improved by application of bio-fertilizer. The flowering ability of a crop is an indispensable component in crop improvement programmes as it is a major determinant of fruit-setting in sexually reproducing crops. Ukwu and Olasanmi (2018) reported positive correlation between number of flowers pollinated and number of fruits set in cassava.
The effect of Kolgrace application rates on number of pods per plant in greengram was highly significant $(p<0.01)$ as shown in Table 7 . The rate $0.5 \mathrm{tha}^{-1}$ produced significantly the highest number of pods plant ${ }^{-1}$ at 8 WAP (9.0), 9 WAP (19.0) and 10 WAP (29.0), while application of $0.25 \mathrm{t} \mathrm{ha}^{-1}$ was highest (42.0) at 11 WAP followed by $0.5 \mathrm{tha}^{-1}$ (41.0). Plants grown without bio-fertilizer were the poorest across the various rates and weeks. The superiority of lower rates of Kolgrace bio-fertilizer $\left(0.25\right.$ and $\left.0.5 \mathrm{t} \mathrm{ha}^{-1}\right)$ for number of pods, over higher rates $\left(1.0,2.0 \mathrm{t} \mathrm{ha}^{-1}\right)$ across the four weeks of data collection supports the notion that greengram does not require heavy fertilizer doses to produce optimally, and could be due partly to its inherent ability to co-exist symbiotically with mycorrhiza fungi on one hand, and nitrifying bacteria on the other hand. This report is coherent with the earlier reports of Kasiamdari et al. (2002) and Mandal et al. (2009). The N-fixing ability of greengram is abundant in literature (Senaratne and Gunasekera, 1994; Heuzé et al., 2015; Razzaque et al., 2016).

Kolgrace application rates did not significantly $(p>0.05)$ influence fresh pod weight (FPY) of greengram, although $0.25 \mathrm{tha}^{-1}$ recorded the highest mean value for FPY (4.94) in contrast to 2.00 which was the least (3.25) (Table 7). However, the effect of Kolgrace bio-fertilizer rates on dry pod yield of greengram was significant at $p<0.01$ (Table 7). Application of 0.25 and $0.50 \mathrm{t} \mathrm{ha}^{-1}$ produced comparable yields of 3.85 and $3.54 \mathrm{tha}^{-1}$ respectively, and were superior $(p<0.05)$ to other rates. The dry pod yield was statistically $(p>0.05)$ similar with no application or with application of 1.0 or $2.0 \mathrm{t} \mathrm{ha}^{-1}$ of bio-fertilizer. A gradual decrease in pod yield was observed with marginal increase in Kolgrace rates above $0.25 \mathrm{t} \mathrm{ha}^{-1}$, which suggests that $0.25 \mathrm{t} \mathrm{ha}^{-1}$ is the threshold, below and above which yield decline is bound to occur. This report is consistent with Ihejiofor et al. (2020) who found $0.5 \mathrm{t} \mathrm{ha}^{-1}$ to be superior in growth and yield indices in the screenhouse.

Table 5: Effect of different rates of Kolgrace biofertilizer on stem diameter

\begin{tabular}{lcccccc}
\hline $\begin{array}{l}\text { Rates } \\
\left(\mathrm{t} \mathrm{ha}^{-1}\right)\end{array}$ & 2 & 4 & 5 & 6 & 7 & 8 \\
\hline 0 & $0.19 \mathrm{a}$ & $0.52 \mathrm{a}$ & $0.71 \mathrm{~b}$ & $0.93 \mathrm{~b}$ & $1.00 \mathrm{~b}$ & $1.03 \mathrm{~b}$ \\
0.25 & $0.22 \mathrm{a}$ & $0.70 \mathrm{a}$ & $1.17 \mathrm{a}$ & $1.11 \mathrm{a}$ & $1.23 \mathrm{a}$ & $1.25 \mathrm{a}$ \\
0.5 & $0.22 \mathrm{a}$ & $0.71 \mathrm{a}$ & $1.04 \mathrm{a}$ & $1.20 \mathrm{a}$ & $1.36 \mathrm{a}$ & $1.43 \mathrm{a}$ \\
1 & $0.8 \mathrm{a}$ & $0.58 \mathrm{a}$ & $0.86 \mathrm{~b}$ & $1.13 \mathrm{a}$ & $1.23 \mathrm{a}$ & $1.36 \mathrm{a}$ \\
2 & $0.18 \mathrm{a}$ & $0.56 \mathrm{a}$ & $1.16 \mathrm{a}$ & $1.12 \mathrm{a}$ & $1.20 \mathrm{a}$ & $1.32 \mathrm{a}$ \\
\hline \multicolumn{7}{l}{ Means with same letter(s) are similar to each other at $p<0.05$}
\end{tabular}

Table 6: Effect of different rates of Kolgrace biofertilizer on number of flowers

\begin{tabular}{lccccc}
\hline Rates & \multicolumn{5}{c}{ Weeks after planting } \\
\cline { 2 - 6 }$\left(\mathrm{t} \mathrm{ha}^{-1}\right)$ & 6 & 7 & 8 & 9 & 10 \\
\hline 0 & $2.0 \mathrm{a}$ & $9.0 \mathrm{c}$ & $4.0 \mathrm{~d}$ & $16.0 \mathrm{c}$ & $15.0 \mathrm{~b}$ \\
0.25 & $2.0 \mathrm{a}$ & $12.0 \mathrm{~b}$ & $7.0 \mathrm{~b}$ & $17.0 \mathrm{~b}$ & $22.0 \mathrm{a}$ \\
0.5 & $2.0 \mathrm{a}$ & $16.0 \mathrm{a}$ & $6.0 \mathrm{c}$ & $16.0 \mathrm{c}$ & $19.0 \mathrm{a}$ \\
1.0 & $2.0 \mathrm{a}$ & $9.0 \mathrm{c}$ & $10.0 \mathrm{a}$ & $21.0 \mathrm{a}$ & $23.0 \mathrm{a}$ \\
2.0 & $3.0 \mathrm{a}$ & $12.0 \mathrm{~b}$ & $10.0 \mathrm{a}$ & $21.0 \mathrm{a}$ & $16.0 \mathrm{~b}$ \\
\hline
\end{tabular}

Means with same letter(s) are similar to each other at $p<0.05$ 
Table 7: Effect of different rates of Kolgrace bio-fertilizer on number of pods and pod yield on fresh and dry basis

\begin{tabular}{|c|c|c|c|c|c|c|}
\hline \multirow{2}{*}{$\begin{array}{l}\text { Treatments } \\
\left(\mathrm{t} \mathrm{ha}^{-1}\right)\end{array}$} & \multicolumn{4}{|c|}{ Number of pods } & \multirow{2}{*}{$\begin{array}{l}\text { Fresh pod yield } \\
\left(\mathrm{t} \mathrm{ha}^{-1}\right)\end{array}$} & \multirow{2}{*}{$\begin{array}{c}\text { Dry pod yield } \\
\left(\mathrm{tha}^{-1}\right)\end{array}$} \\
\hline & $8 \mathrm{WAP}$ & $9 \mathrm{WAP}$ & $10 \mathrm{WAP}$ & $11 \mathrm{WAP}$ & & \\
\hline 0 & $4.0 \mathrm{~d}$ & $8.0 \mathrm{e}$ & $18.0 \mathrm{e}$ & $29.0 \mathrm{e}$ & $3.50 \mathrm{a}$ & $2.62 \mathrm{~b}$ \\
\hline 0.25 & $8.0 \mathrm{~b}$ & $15.0 \mathrm{~b}$ & $26.0 \mathrm{~b}$ & $42.0 \mathrm{a}$ & $4.94 \mathrm{a}$ & $3.85 \mathrm{a}$ \\
\hline 0.5 & $9.0 \mathrm{a}$ & $19.0 \mathrm{a}$ & $29.0 \mathrm{a}$ & $41.0 \mathrm{~b}$ & $4.65 \mathrm{a}$ & $3.54 \mathrm{a}$ \\
\hline 1.0 & $5.0 \mathrm{c}$ & $13.0 \mathrm{c}$ & $23.0 \mathrm{c}$ & $40.0 \mathrm{c}$ & $3.68 \mathrm{a}$ & $2.61 \mathrm{~b}$ \\
\hline 2.0 & $5.0 \mathrm{c}$ & $11.0 \mathrm{~d}$ & $22.0 \mathrm{~d}$ & $36.0 \mathrm{~d}$ & $3.25 \mathrm{a}$ & $2.22 \mathrm{c}$ \\
\hline
\end{tabular}

Means with same letter(s) are similar to each other at $p<0.05$. WAP - weeks after planting

Kolgrace application rates did not significantly $(p>0.05)$ influence fresh pod weight (FPY) of greengram, although $0.25 \mathrm{t} \mathrm{ha}^{-1}$ recorded the highest mean value for FPY (4.94) in contrast to 2.00 which was the least (3.25) (Table 7). However, the effect of Kolgrace bio-fertilizer rates on dry pod yield of greengram was significant at $p<0.01$ (Table 7). The rates 0.25 and $0.50 \mathrm{t} \mathrm{ha}^{-1}$ produced comparable yields of 3.85 and $3.54 \mathrm{tha}^{-1}$ respectively, and were statistically $(p<0.05)$ superior to other rates. The dry pod yield was statistically $(p>0.05)$ similar with no application or with application of 1.0 or $2.0 \mathrm{t} \mathrm{ha}^{-1}$ of biofertilizer. A gradual decrease in pod yield was observed with marginal increase in Kolgrace rates above $0.25 \mathrm{t} \mathrm{ha}^{-1}$, which suggests that $0.25 \mathrm{t} \mathrm{ha}^{-1}$ is the threshold, below and above which yield decline is bound to occur. This report is consistent with Ihejiofor (2020) who found $0.5 \mathrm{tha}^{-1}$ to be superior in growth and yield indices in the screenhouse.

\section{CONCLUSION}

The effect of varying rates of Kolgrace bio-fertilizer was significant in all the traits measured with exception to fresh pod yield. Application rate of 0.5 $\mathrm{t} \mathrm{ha} \mathrm{a}^{-1}$ produced consistently higher results for all growth traits measured as growth parameters were significantly retarded with rates less or greater than $0.5 \mathrm{t} \mathrm{ha}^{-1}$. However, $0.25 \mathrm{t} \mathrm{ha}^{-1}$ was superior in yield and yield indices. It was observed in this study that for any marginal increase in Kolgrace rate above $0.25 \mathrm{t} \mathrm{ha}^{-1}$, a gradual decline in yield was observed which suggest that $0.25 \mathrm{tha}^{-1}$ is the threshold for yield, below or above which, yield decline is bound to occur. In addition, the significantly higher performance of 0.25 and $0.5 \mathrm{t}$ ha $^{-1}$ of Kolgrace bio-fertilizer over higher rates emphasized the ability of the bio-fertilizer to provide supplemental nutrients in a balanced proportion to crops without degrading the environment or accumulating deposits of chemical residues in sinks as is the case with inorganic fertilizers when used inappropriately. As such Kolgrace bio-fertilizer should be considered as an alternative to chemical fertilizer and manures for sustainable agriculture as it contains higher doses of most critical essential nutrient elements relative to other conventional manures.

It is therefore recommended to use Kolgrace application rate of $0.5 \mathrm{t} \mathrm{ha}^{-1}$ if the interest of the farmer is sprout, fodder or green manure and $0.25 \mathrm{t}$ $\mathrm{ha}^{-1}$ if the interest is for seed production.

\section{REFERENCES}

Adeniyan O.N., Ojo A.O., Akinbode O.A. and Adediran J.A. (2011). Comparative study of different organic manure and NPK fertilizer for improvement of soil chemical properties and dry matter yield of maize in two different soils. J. Soil Sci. Environ. Manage., 2 (1), 9-13

Agbede T.M., Ojeniyi S.O. and Adeyemo A.J. (2008). Effect of poultry manure on soil physical and chemical properties, growth and grain yield of sorghum in Southwest Nigeria. Am. Eurasian J. Sustainable Agric., 2 (1), $72-77$

Ajoku M.C., Ngwuta A.A. and Okoli N.A. (2019). Response of mungbean genotypes to organic and inorganic fertilizers in Owerri, Southeastern Nigeria. Proc. the $6^{\text {th }}$ Natl. Conf. Crop Sci. Soc. Nig., Owerri, pp. 581-592

Akinmutimi A.L. and Amaechi C. (2015). Comparative effects of poultry manure, piggery and NPK fertilizer on growth, yield and nutrient content of okra (Abelmoschus esculentus). Int. J. Cur. Res. Rev., 7 (12), 1-6

Al-Jawhara A.A. (2016). Comparative study of synthetic fertilizer and organic manure on some mungbean (Vigna radiata L. Wilczek) genotype 1 effect on growth parameters and photosynthetic productivity. Am. Eurasian J. Agric. Environ. Sci., 16 (4), 666-676

Anjum N.A., Umar S., Iqbal M., Khan N.A. (2011). Cadmium causes oxidative stress in mungbean by affecting the antioxidant enzyme system and ascorbate glutathione cycle metabolism. Russian $J$ Plant Physiol., 58, 92-99

AVRDC (2012). Mung bean. Annual Report of Asian Vegetable Research and Development Center, World Vegetation Center

Cao D., Li H., Yi J., et al. (2011). Antioxidant properties of the mungbean flavonoids on alleviating heat stress. PLoS One, 6, e21071

Gadi P., Dawson J. and Shankar M. (2017). Effect of different organic manures, inorganic fertilizers and growth regulator on yield attributes and yield of greengram (Vigna radiate L.). Int. J. Curr. Res. 12, 1567-1572. DOI: 10.15740/HAS/AU/12

Heuzé V., Tran G., Bastianelli D., Lebas F. (2015). Mung bean (Vigna radiata). Feedipedia, a programme by INRA, CIRAD, AFZ and FAO. http://www.feedi pedia.org/node/235

Ihejiofor P.N., Ukwu U.N. and Adeoye G.O. (2020). Comparative effects of different levels of Kolgrace organic fertilizer on the growth and yield attributes of greengram (Vigna radiata L. Wilczek) in the screenhouse. Asian J. Res. Agric. Forest., 6 (3), 1-7. https://doi.org/10.9734/AJRAF/2020/v6i330104

Kannaiyan S. (1999). Bio-resource Technology for Sustainable Agriculture. Associated Publishing Company, New Delhi, p. 422 
Kasiamdari R.S., Smith S.E., Smith F.A. and Scott E.S. (2002). Influence of the mycorrhizal fungus, Glomaus coronatum and soil phosphorus on infection and disease caused by binucleate Rhizoctonia and Rhizoctonia solani on mung bean (Vigna radiata). Plant Soil, 238, 235-244

Kim D.K., Jeong S.C., Gorinstein S. and Chon S.U. (2012). Total polyphenols, antioxidant and antiproliferative activities of different extracts in mungbean seeds and sprouts. Plant Food Human Nutr., 67, 71

Kirk P.L. (1950). Kjeldahl method for total nitrogen. Analytical Chemistry, $22 \quad$ (2), $354-358$ https://doi.org/10.1021/ac60038a038

Lawn R.J. and Ahn C.S. (1985). Mungbean (Vigna radiata L. Wilczek and Vigna rnungo L. Hepper). In: Summerfield R.J. and Roberts E.H. (eds.), Grain Legume Crops (pp. 584-623). Collins, London

Lawn R.J. and Russell J.S. (1978). Mungbeans: A grain legume for summer rainfall cropping areas of Australia. J. Aust. Inst. Agric. Sci., 44, 28-41

Mahabub S.K., Khan S.H., Mazed H.E.M., Sarker S. and Hassan M.T. (2016). Effect of cow manure on growth, yield and nutrient content of mungbean. Asian Res. J. Agric., 2 (1), 1-6

Malik M.A., Khan K.S., Marschner P. and Ali S. (2013). Organic amendments differ in their effect on microbial biomass and activity and on $\mathrm{P}$ pools in alkaline soils. Biol. Fertil. Soils, 49, 415-425. https://doi.org/10.1007/s00374-012-0738-6

Mandal S., Mandal M. and Das A. (2009). Stimulation of indole acetic acid production in a rhizobium isolate of Vigna mungo by root nodule phenolic acids. Arch. Microbiol., 191, 389-393

Meloche V.N. (1956). Flame photometric determination of sodium and potassium, Anal. Chem., 28, 1844-1847

Mian I.A., Ahmad B., Khan S., Khan B., Dawar K. et al. (2020). Improving wheat productivity and soil quality through integrated phosphorus management with residual effect of biochar. J. Saudi Chem. Soc., 25, 1-6. https://doi.org/10.1016/j.jscs.2020.11.008

Nair R.M., Schafleitner R. and Lee S. (2020). The mungbean genome. In: Compendium of Plant Genomes (pp. 1-7). Springer Nature, Switzerland

Obalum S.E., Okpara I.M., Obi M.E. and Wakatsuki T. (2011). Short-term effects of tillage-mulch practices under sorghum and soybean on organic carbon and eutrophic status of a degraded Ultisol in southeastern Nigeria. Trop. Subtrop. Agroecosys., 14 (2), 393-403
Obalum S.E., Nwite J.C., Watanabe Y., Igwe C.A. and Wakatsuki T. (2012). Comparative topsoil characterization of sawah rice fields in selected inland valleys around Bida, north-central Nigeria: physicochemical properties and fertility status. Trop. Agric. Dev., 56 (2), 39-48. https://doi.org/10.11248/jsta.56.39

Ogunwale J.A., Olaniyan J.O. and Auloju M.O. (2002). Morphological, physiochemical and clay mineralogical properties of soils overlaying basement complex rocks in Ilorin East, Nigeria. Moor J. Agric. Res., 32, 147-154

Omar I.M.A., Muaiad H.I.A., Ahmed R.M.A. and Saleh E.S. (2020). Effect of water stress and organic fertilization sources on maize growth and yield. Int. J. Agric. Stat., 16 (1), 271-279

Onwurafor E.U., Uzodinma E.O., Uchegbu N.N., Ani J.C., Umunnakwe I.L. and Ziegler G. (2020). Effect of malting periods on the nutrient composition, antinutrient content and pasting properties of mungbean flour. Agro-Science, 19 (1), 18-24. https://doi.org/10.4314/as.v19i1.3

Rachie K.O. and Roberts L.M. (1974). Grain legumes for the lowland tropics. Adv. Agron., 26, 1-132

Razzaque M.A., Haque M., Karim A. and Solaiman A.R.M. (2016). Nitrogen fixing ability of mungbean genotypes under different levels of nitrogen application. Bangladash J. Agric. Res., 41 (1), 163. https://doi.org./10.3329/bjar.v41i1.27681

Sadeghipour O., Monem R. and Tajali A.A. (2010). Production of mungbean (Vigna radiata L.) as affected by nitrogen and phosphorus bio-fertilizer application. J. Appl. Sci., 10 (10), 843-847

Senaratne R. and Gunasekera M.T.K. (1994). Nitrogen fixation, growth and yield of intercropped mungbean (Vigna radiate L.) and groundnut (Arachis hypogaea L.) as affected by the genotype. J. Agron. Crop Sci. https://doi.org/10.1111/j.1439-037X.1994.tb00573.x

Steiner F., Zufo A.M., Echer M.M. and Guimaraes V.F. (2019). Collard green yield and nutritional quality with mineral and organic fertilization. Ciencias Agrarias Londrina, 40 (5), 2165-2178

Thulin M. (1989). Fabaceae (Leguminosae). In: Hedberg I. and Edwards S. (eds.), Flora of Ethiopia (pp. 49251). Asmara and Uppsala, Addis Ababa

Ukwu N.U. and Olasanmi B. (2018). Crossability among five Cassava (Manihot esculenta Crantz) Varieties. Modern Concepts Dev. Agron., 2 (4), 1-6 